\title{
A Survey of the Mobile Phone-Based Interventions for Violence Prevention Among Women
}

\author{
Sunny Sinha \\ Aviral Shrivastava \\ Christiana Paradis
}

\begin{abstract}
Information Communication Technologies (ICT), particularly mobile phone technology, has increased the propinquity between individuals by enhancing their ability to frequently communicate with one another through different mediums, like text, audio, video, and emojis. Cell phone technology is being used to combat various social issues, including several public health-related problems such as violence against women. Over the past two decades several cellphone-based apps, including Circle of 6, MyPlan, Panic Button, and Aspire News have been developed in several countries to prevent violence against women. Anecdotal evidence suggests that these apps are effective both as violence prevention and as an intervention tool in public as well as private spaces. However, very little awareness exists among social workers about these mobile phone applications (apps), particularly the capabilities and limitations of these apps. Based on a brief survey and classification of the existing mobile phone apps designed to prevent violence against women, this paper aims to explain how these apps work, and point out their capabilities and limitations so that social workers and public health professionals can better guide their clients in using these technology-based services. It is highly recommended that social workers evaluate how their clients are affected by the use or non-use of violence prevention apps and advocate for their client's right to digital literacy and internet access.
\end{abstract}

Keywords: Cellphone-based; violence prevention; violence intervention; ICT; health; social work practice

Cell phones are ubiquitous. Even in 2014, $90 \%$ of adults in the U.S. had cell phones, and 55\% could access the Internet through mobile data (Shaw \& Lee, 2014). Mobile phones are not only being used to increase propinquity between individuals by enhancing their ability to frequently communicate with one another through different mediums (e.g., text, audio, video, emojis, etc.), but are also being used by women as subtle means of selfdefense (by calling someone when they are walking alone in a perceived risky location), and are even reported to be more effective than pepper spray (Cumiskey \& Brewster, 2012). Cell phones are already in use to aid in several public health-related problems, including adherence to diabetes treatment (Kwon et al., 2004), smoking cessation (Obermayer, William, Ofer, \& Jersino, 2004; Rodgers et al., 2005; Vidrine, Arduino, Lazev, \& Gritz, 2006), suicide prevention (Aguirre, McCoy, \& Roan, 2013) and adherence to HIV treatment (Dean, Makin, Kydd, Biriotti, \& Forsyth, 2012; Ingersoll et al., 2014; Mbuagbaw et al., 2012; Puccio et al., 2006; Rodrigues et al., 2012). For example, the SEXINFO program, developed by Levine, McCright, Dobkin, Woodruff, and Klausner (2008), is an SMS text messaging-based program for adolescents in the San Francisco area through

Sunny Sinha, Ph.D., Associate Professor, School of School Work, Marywood University, Scranton, PA-18509;

Aviral Shrivastava, Ph.D., Associate Professor, School of Computing, Informatics, and Decision Systems Engineering, Arizona State University, Tempe, AZ-85281; Christiana Paradis, MSW, Adjunct Faculty, Susquehanna University, Selinsgrove, PA 17870. 
which teens can text message "SEX INFO" to a five-digit number from a cell phone to receive information on sexual health-related matters. Once the user sends the text message, they receive a message instructing them to text back an appropriate code related to their question (for instance, B3 for HIV prevention). Depending on the code entered, the users will receive a text message with all the information about sexual health and referral to a local sexual health organization working with youths.

Over the last decade - ever since smartphones became popular - several cell phone apps, such as bSafe, Circle of 6, Hollaback!, Panic Button, LifeLine Response, and Guardly, (Brathwaite, 2012; Jones, 2014; Rosenthal, 2013; Zraick, 2010) have been developed to address the general issue of women's safety. Typically, these smartphonebased apps enable users to send predetermined text messages to their registered emergency contacts along with the global positioning system (GPS) location and physical address by just shaking the device or pressing the panic alarm /danger alert button. A few of the smartphone apps come with features that enable users to get connected with nearby support services, such as pre-programmed hotline numbers along with the contact information of nearby police stations, hospitals, social networking sites, and other counseling services. Since most of these apps do not have user evaluation built, very little can be said about the effectiveness of these apps based merely on the number of downloads (Westmarland et al., 2013).

A study interviewing 10 women residing at a domestic violence shelter in the United States revealed that not knowing how to securely and privately use the social networking sites was primarily responsible for women refraining from using their mobile phones (Dimond, Fiesler, \& Bruckman, 2011) even though they admitted that it was a valuable tool for seeking social support. A randomized controlled trial study was designed to evaluate the effectiveness of the MyPlan app, an interactive safety decision-making webbased and smartphone application (app) for college women survivors of intimate-partner violence and their friends. This study found that after 12 months of using this app, the percentage of students experiencing physical or sexual abuse declined, and the support groups of survivors of violence were more prepared to help their friend leave the relationship safely (Glass, Eden, Bloom, \& Perrin, 2010). Users of the MyPlan app also pointed out that the electronic medium of communication was preferred, and not having to discuss "face-to-face" at the counseling center reduced the social desirability bias in their responses (Alhusen, Bloom, Clough, \& Glass, 2015; Eden et al., 2014; Glass et al., 2015; Glass et. al., 2017; Lindsay et al., 2013).

The discourse about using Information Communication Technologies (ICTs) such as mobile phones and the internet to tackle the issue of violence against women has remained slanted with a heavy focus on the negative effects of technology on the lives of individuals, such as invasion of privacy, confidentiality, and the technology-facilitated marginalization and sexual victimization of individuals, such as cyberbullying, cyberstalking, sexting and cyberharassment (Dimond et al., 2011; Henry \& Powell, 2015; Martinez-Pecino \& Durán 2016; Mason \& Magnet, 2012). However, it cannot be negated that much of the technology-related problems stem from users not knowing how the issues of security, surveillance, privacy, and confidentiality are tackled in each of these apps (Mason \& Magnet, 2012). 
Social work scholars also increasingly argue that technology-based interventions can enhance social work practice, as it ensures continuity, client engagement, affordability and accessibility of services (Craig \& Lorenzo, 2014; Ramsey \& Montgomery, 2014). However, since many disenfranchised and marginalized communities do not have access to ICTs or the internet, scholars have argued that social workers should actively advocate for policy and program initiatives that addresses these infrastructural gaps related to technology(Perron, Taylor, Glass, \& Margerum-Leys, 2010). In 2017, four prominent social work organizations, the National Association of Social Work (NASW), Association for Social Work Boards (ASWB), Council for Social Work Education (CSWE), and CSWA (Clinical Social Work Association) recognized that technology is transforming the social work practice arena, particularly the nature of the client-worker relationship, and came together to adopt a uniform set of technology standards focused on addressing issues that arise with social worker and client use of technology (NASW, 2017b). The NASW and the ASWB Standards for Technology and Social Work Practice recommend that "social workers should be proficient in the technological skills and tools required for competent and ethical practice and for seeking appropriate training and consultations to stay current with emerging technologies" (as cited by Lopez, 2014, p. 821). Yet, most social work undergraduate and graduate programs do not prepare their students to achieve digital literacy (Craig \& Lorenzo, 2014; Robbins, Coe Regan, Williams, Smyth, \& Bogo, 2016), defined by Hague (2010) as " the ability to participate in a range of critical and creative practices that involve understanding, sharing and creating meaning with different kinds of technology and media" (p. 3).

The knowledge and awareness among social workers about the new Information and Communication Technologies (ICT), and in particular cellphone applications, how they work, what are their capabilities and limitations, and how they can be meaningfully used to enhance the quality of lives of their clients remain limited (Parrott \& Madoc-Jones, 2008; Perron, Taylor, Glass, \& Margerum-Leys, 2010). The findings from a qualitative study aimed at examining domestic violence service provider's needs and perceptions of using technology found that service providers have limited experience and knowledge about technological advances which resulted in them feeling anxious and uncertain about their abilities to use and learn new technological advances. Therefore, ongoing ICT related training and support needs to be provided to social workers for them to be able to effectively address technology-related concerns and questions that may arise in therapy for their clients and themselves (Murray, Nemati, White, Chow, \& Pow, 2015).

This article provides a survey, comparison, and classification of the existing cell phone-based violence prevention/intervention applications (apps). First, we present an overview and classification of violence prevention apps. Second, we discuss the metrics of evaluation we used to compare and contrast the various violence prevention apps. Third, we provide a brief overview of how these apps work, their capabilities, limitations, and focus area. Fourth, we offer an analysis of what features of the apps work well and what aspects need improvement. Finally, we conclude by discussing the implications of these violence prevention apps for social work practice and future research. 


\section{Overview and Classification}

The existing mobile phone-based apps designed to prevent violence against women can be classified into three broad categories: a) Crowdsourcing reporting apps, b) Emergency assistance apps, and c) Self-assessment/ learning apps. The crowdsourcing reporting apps attempt to tie violence to users' space/location (geography) enabling them to report incidents of violence, and then put them on a map to visualize the violence "hotspots." These apps not only help collect data on violent incidents in the community, but they may be used by local law enforcement in deciding where to concentrate their surveillance efforts, and by ordinary individuals to determine which spaces to avoid. The second category of apps is the emergency assistance apps, which is by far the largest category. These apps have been designed to enhance the personal safety of users. To use these apps effectively, users must first enter contact information for their preferred emergency contacts. Then, when users are in an emergency situation, they can trigger an SOS alert which sends messages to their emergency contacts. Some apps also allow users to call emergency dispatch when the emergency alert is triggered. The third category of apps is the self-help learning/assessment apps. These apps are designed to increase users' understanding of violence and also engage in self-learning and self-assessment of their risk of abuse. They may also link users to supportive services, including lawyers, social and community workers, shelters, and clinics.

The following section discusses the evaluation metric used to compare and contrast the various categories of violence prevention apps. Prior researchers have used a similar metric to evaluate mobile phone apps developed in the other fields such as suicide prevention (Aguirre et al., 2013) and unintended pregnancy prevention (Mangone, Lebrun, \& Muessig, 2016).

\section{Evaluation Metric for Violence Prevention Apps}

1. Stated Purpose - The stated purpose of the app is an important metric because it clarifies to users what life problems they can solve using these apps. Mancini \& O'Reilly (2013) argue that the socio-cultural, and political contexts vary widely among communities, and therefore one technological solution may not be equally effective across different communities. Therefore, the context driven nature of the stated purpose of the apps is an important metric to judge the usability of the app.

2. Privacy - Another important consideration for violence prevention apps includes how much personal information users are required to disclose in order to use the app for its stated purpose. For example, a lengthy registration procedure, or a registration procedure that asks several personal questions (e.g., name, date of birth, location) from the users can be a strong deterrent in using the app. There can be even more subtle deterrents to the use of apps. For example, a well-known icon of the app may be a problem for survivors of domestic violence who live close to the abusers and are always under surveillance by their abusers. Therefore, the apps' ability to report incidents anonymously and the password or PIN features are a critical factor in enhancing the effectiveness of these apps (Aguirre et al., 2013).

3. Ease of use - This metric assesses the understandability of the app. For example, if the user wants to report an incident, they should have the option to either write a text 
description of the incident or submit audio or video report. In addition, if users have to fill too many required fields before submitting the report, then it may act as a deterrent. Therefore, the option to select 'fields' that are pertinent to their situation will prove crucial in enhancing the usability of these apps.

4. Geography -To be usable, an app should fit the socio-cultural profile of the place, including language requirements. As a result, apps may not be as useful for other geographical regions. In addition, what languages are supported in the app?

5. Access to supportive services/resources - Access to supportive services is an essential aspect of violence prevention apps, especially emergency-assistance apps. Some apps may only connect to user's friends and family, while others can connect to private security, law enforcement, and first responders.

6. Affordability-Cost is an important consideration since the individuals who are at an increased risk of violence are often socially and economically marginalized individuals (Heerde \& Hemphill, 2019; Walls et al., 2019). Therefore, it is critical to assess if there is an additional cost associated with using the app. For instance, while an app could be free, essential and helpful features may be locked behind a paywall, requiring users to make an in-app purchase to unlock premium features.

\section{Survey of Mobile Phone Violence Prevention Apps}

Crowdsourcing reporting apps. Crowdsourcing reporting apps allow users to access a website via a smartphone or computer. Once on the designated site, users can fill out a violence incident report. The incident report is then logged in real-time through an interactive map and enables identification of "hot spots"- referred to as places with the most frequent reports of violence. Crowdsourcing reporting apps serve four purposes. First, they create a database of information about gender-based violence incidents happening in cities or towns across select countries. Second, to help prevent violence, the institutions collecting the data can use it to advocate for increased patrols by local law enforcement authorities in what emerges as the "hot spots". Third, users can access these interactive maps and get an understanding of places that can be dangerous, or violence-prone as the maps identify the "hot spots" for violence. Finally, reports can be submitted by victims as well as by bystanders witnessing the incident. For instance, I've got your back campaign was launched by Hollaback! in collaboration with Green Dot to encourage bystanders to upload their anecdotes as witnesses to street harassment, allowing bystanders to show their support for people sharing their stories of violence (Livingston, Wagner, Diaz, \& Liu, 2012).

Table 1 provides a comparative overview of four projects using crowdsourcing reporting apps to gain a nuanced understanding of the issue of violence against women in their communities. For instance, these apps allow for clarity to emerge on who are the perpetrators, what type of violence gets frequently reported, and in which sites these violent incidents are being reported. Please note that, even after our best efforts, the list below may not be exhaustive, but we believe we have covered all the major variations of the apps to examine their strengths and limitations. 
Table 1. Overview and Features of Projects Using Crowdsourcing Reporting Apps

\begin{tabular}{|c|c|c|c|c|c|c|}
\hline $\begin{array}{l}\text { Name of } \\
\text { crowdsourcing apps }\end{array}$ & Purpose & Privacy & Ease of use & Geography & $\begin{array}{l}\text { Access to supportive } \\
\text { service \& resources }\end{array}$ & Affordability \\
\hline $\begin{array}{l}\text { GBV project } \\
\text { Cambodia }\end{array}$ & $\begin{array}{l}\text { To combat \& } \\
\text { eliminate gender- } \\
\text { based violence in } \\
\text { Cambodian society. }\end{array}$ & $\begin{array}{l}\text { Identifying information is } \\
\text { optional when making } \\
\text { reports using web form. } \\
\text { Anonymous reporting } \\
\text { permitted. }\end{array}$ & $\begin{array}{l}\text { Users can report incident in their text. } \\
\text { Users need to select the type of harm \& the } \\
\text { location where violent incident occurred. } \\
\text { Available to users in their language } \\
\text { (Khmer). } \\
\text { Users can upload photos \& videos of } \\
\text { incidents. }\end{array}$ & Cambodia & Only for reporting. & $\begin{array}{l}\text { Internet } \\
\text { access fee }\end{array}$ \\
\hline $\begin{array}{l}\text { HarassMap, } \\
\text { Egypt }\end{array}$ & $\begin{array}{l}\text { To end all forms of } \\
\text { sexual harassment } \\
\text { encountered by } \\
\text { women in public } \\
\text { spaces }\end{array}$ & $\begin{array}{l}\text { Identifying information } \\
\text { required when using } \\
\text { SMS, Facebook, email or } \\
\text { Twitter to make a report. } \\
\text { Identifying information is } \\
\text { optional when preparing } \\
\text { reports using a web form. } \\
\text { Anonymous reporting } \\
\text { permitted. }\end{array}$ & $\begin{array}{l}\text { Users can report incidents using web-based } \\
\text { forms in which they have to describe } \\
\text { incidents in text, select the type of harm } \\
\text { applicable in their situation, \& the location } \\
\text { of incidents. } \\
\text { Other ways to report are SMS, Facebook, } \\
\text { email, or Twitter (HarassMap, 2015). }\end{array}$ & Egypt & $\begin{array}{l}\text { Free legal services, } \\
\text { psychological } \\
\text { support, \& lawyers } \\
\text { Self-defense classes } \\
\text { Information how to } \\
\text { file police reports } \\
\text { Information on how } \\
\text { to deal with phone } \\
\text { harassment }\end{array}$ & $\begin{array}{l}\text { Internet } \\
\text { access fee }\end{array}$ \\
\hline $\begin{array}{l}\text { Hollaback! } \\
\text { Multiple countries }\end{array}$ & $\begin{array}{l}\text { To end street } \\
\text { harassment against } \\
\text { women \& LGBTQ } \\
\text { communities in } \\
\text { public spaces. }\end{array}$ & $\begin{array}{l}\text { Registration required for } \\
\text { the app (must create a } \\
\text { log-in or Facebook log- } \\
\text { in) but the option to } \\
\text { remain anonymous while } \\
\text { making reports is always } \\
\text { there. } \\
\text { Identifying information is } \\
\text { optional when making } \\
\text { reports using a web form. }\end{array}$ & $\begin{array}{l}\text { Users can make online reports of incidents } \\
\text { by sharing their story in text. Entry is } \\
\text { optional but encouraged for users. } \\
\text { Users can upload photos \& videos of } \\
\text { incidents. } \\
\text { Users can choose more than one form of } \\
\text { street harassment from list while making } \\
\text { reports. } \\
\text { Fewer required fields for submitting } \\
\text { reports, so users can report as much or as } \\
\text { little information as they desire. }\end{array}$ & $\begin{array}{l}\text { Region: More } \\
\text { than } 30 \\
\text { countries in } \\
\text { Europe }\end{array}$ & $\begin{array}{l}\text { Provides information } \\
\text { for local sexual } \\
\text { assault centers. }\end{array}$ & $\begin{array}{l}\text { Internet } \\
\text { access fee }\end{array}$ \\
\hline $\begin{array}{l}\text { Women Under Siege, } \\
\text { Ukraine \& Syria }\end{array}$ & $\begin{array}{l}\text { To end rape \& all } \\
\text { forms of sexualized } \\
\text { violence occurring } \\
\text { against women in } \\
\text { conflict-prone } \\
\text { regions. }\end{array}$ & $\begin{array}{l}\text { Identifying information is } \\
\text { optional when preparing } \\
\text { reports using the web } \\
\text { form. } \\
\text { Anonymous reporting } \\
\text { allowed }\end{array}$ & $\begin{array}{l}\text { Users can report incidents in text \& create a } \\
\text { title for incidents. } \\
\text { Description of incidents, title of incidents, } \\
\text { type of harm \& location where violent } \\
\text { incident occurred are required information } \\
\text { for form to be submitted. } \\
\text { Users can upload photos \& videos of } \\
\text { incidents. }\end{array}$ & $\begin{array}{l}\text { Ukraine, } \\
\text { Lebanon, \& } \\
\text { the Middle } \\
\text { East }\end{array}$ & $\begin{array}{l}\text { Used only for } \\
\text { reporting. }\end{array}$ & $\begin{array}{l}\text { Internet } \\
\text { access fee }\end{array}$ \\
\hline
\end{tabular}


SMS alert-based Emergency assistance apps. Numerous cell phone applications (apps) have been designed to enhance the personal safety of the users. The way to operate these apps is first to enter information about the users' emergency contacts so that the app can contact them when an emergency arises. When users press the "help" button within the app, it will send out automated SMS alert messages to the listed emergency contacts along with the GPS coordinates of the users. Some of the apps also have the feature to automatically connect users with first-line responders, such as the police, firefighters, and medical personnel when pressing the "help" button within the app. Table 2 provides an overview of the different types of SMS alert-based emergency assistance apps for violence prevention and intervention. We have included many different models of cell phone apps to facilitate a more in-depth understanding among social workers about the various ways in which these cell phone apps can be designed to address the specific needs of their clientele. However, by no means is the list exhaustive.

Self-help learning/assessment Apps. The last category reviewed in this survey are apps that are designed to increase the user's understanding of violence and also engage in self-learning and self-assessment of their risk of abuse/danger in the relationship. Table 3 lists some of these self-help learning/assessment apps. We have included different types of self-help learning/assessment apps to facilitate an understanding among social workers of how apps can be designed and used to promote education and learning among their clients about dating violence, domestic abuse, and healthy relationships.

\section{Critical Analysis of the Violence Prevention Apps}

Violence against women is a highly sensitive and stigmatized issue. The term "violence against women" (VAW) falls on a continuum, and refers to several different types of violences including, domestic violence, rape, IPV, sexual harassment, or any other term referenced typically in the mainstream anti-violence literature. Hooks (2000) argues the terminology violence against women/patriarchal violence denotes the connection between acts of violence and the systemic structures of oppression. In other words, violence experienced by women both inside and outside the home is linked with and sustained by the other matrices of domination, including racism, sexism, homophobia/transphobia, ableism, and neoliberalism (Collins,1999; Hooks, 2000; Mason \& Magnet, 2012). However, in many cultures, including the United States, India, Egypt, Cambodia, United Kingdom, and Syria, women tend to internalize the blame and shame for their experience with violence/abuse. This prevents women from stepping forward to take action against the perpetrators of violence (Kalra \& Bhugra, 2013; Overstreet \& Quinn, 2013). Therefore, it is crucial that violence prevention interventions (both cell phone apps-based interventions as well as traditional interventions) aim to empower their users by reducing the culture of victim-blaming that exists in these societies. For instance, both \#MeToo and Time's Up movement are rare examples of 'ICTs-based interventions that have successfully reframed the understanding of violence against women to be a social and cultural problem (Hostler \& O'Neil, 2018). In the following section, we use the evaluation metric discussed previously to critically evaluate the three categories of cell phone-based violence prevention interventions. 
Table 1. Features of Emergency Assistance Apps

\section{Name of the}

App, Location

Pukar, India $\quad$ Push button alerts five pre-registered contacts with

SMS \& location details of user. Emergency contact

can then choose to send SMS to local police

response team who then tracks incidents.

Phone automatically switches to silent mode \& GPS tracking device is turned on.

EyeWatch, Panic button sends SMS \& email alerts, as well as

India $\quad$ initiating phone calls to designated emergency

contacts one after other (calls are on

speakerphone).

In case of false alarm, or once user is safe, safety confirm feature allows users to message their emergency contacts \& confirm their safety.

Circle of Six,

Free personal safety mobile app that allows users to

Internationally seek help from their chosen circle of 6 emergency contacts under crisis situations. With two taps on app, users can send SMS to their 6 contacts with GPS location (if enabled) \& message about nature of assistance needed from them. For instance, app is designed to send "Come get me," "Call me," or "I need to talk" messages.

Panic Button, Free mobile app that allows users to discretely \& Internationally rapidly alert their three trusted contacts in an emergency. Maps of users' location (if GPS is enabled) can be sent by pressing power button.

\section{Uniqueness of the app}

Police will receive signal only when one of your emergency contacts forwards SOS alert SMS on a number given in message.

Unlike other apps, panic button can record 60 seconds of audio-visual information before it was activated $\&$ send it to your emergency contacts \& police control rooms.

In cases of false alarm triggered by users, gives an option to turn off panic alert \& notify contacts with message that user is safe \& it was a false alarm.

Also has accelerometer-based trigger which automatically alerts your emergency contacts when phone detects a sudden jerk or fall.

In addition to personal safety, app also provides users education about sexuality, healthy relationships, \& safety, by explaining abuse, understanding consent, how to say no, sexual safety, safety plans.

Also has direct access to national hotlines like LGBTQ, suicide prevention, AIDS info., national DV, planned parenthood, \& others.

Unlike other apps, alerts discreetly \& rapidly by pressing phone's power button.

Data sent is protected with disguised screen \& pin code.
Limitations/Obstacles for social work clients

Acts only as a deterrent or SOS device.

Users cannot directly contact police.

Requires users to purchase data package for its features to become operational.

\section{Registration is required to use app.}

Access to local police \& other support services is through your call guardians.

Option of directly contacting police is not available; no access to supportive services.

Users must enter six emergency contacts for app to start working. Without six contacts app will not work.

App requires a couple of taps to send alerts to user's 6 contacts \& that can be difficult.

Smartphone only app; cannot operate on a basic phone.

Indirect cost of purchasing data plans.

Economically marginalized clients cannot afford cost of smartphones which are typically higher than traditional phones.
Type of Violence; Target Audience; Link to App Street-based violence

Individuals

http://peopleforparity.org /pukar-app/

Street-based violence prevention app

Individuals

https://eye-

watch.in/Login.action

\section{Street-based violence}

prevention \&

intervention app

Individuals at risk of

violence

http://www.circleof6app $\mathrm{com} /$ (Circle of 6, 2016)

Street-based violence prevention app

https://www.amnesty.org len/latest/campaigns/201 5/07/panic-button-oneyear-on/ (Amnesty International, 2016) 


\begin{tabular}{|c|c|c|c|c|}
\hline $\begin{array}{l}\text { Name of the } \\
\text { App, Location }\end{array}$ & Features of the app & Uniqueness of the app & $\begin{array}{l}\text { Limitations/Obstacles for social work } \\
\text { clients }\end{array}$ & $\begin{array}{l}\text { Type of Violence; Target } \\
\text { Audience; Link to App }\end{array}$ \\
\hline $\begin{array}{l}\text { bSafe, } \\
\text { USA }\end{array}$ & $\begin{array}{l}\text { Free mobile app that allows users to seek help in } \\
\text { emergency/ dangerous situations by tapping SOS } \\
\text { guardian alert button. Immediately notifies user's } \\
\text { friends \& family members that they need help \& let } \\
\text { them know where they are (GPS) \& what's } \\
\text { happening (video \& voice). Will set off a siren } \\
\text { (optional) \& flashlight. } \\
\text { Asks user's preset contacts to walk them home with } \\
\text { "Follow Me" feature of app, which sends live GPS } \\
\text { trace to friends } \\
\text { Timer Mode allows user to program automatic } \\
\text { alarm which will trigger if users fail to check in } \\
\text { within specified time. } \\
\text { "I am Here" can be used by users to let their pre- } \\
\text { selected contacts know where they are right now. } \\
\text { 'Fake Call' allows users to make phone ring } \\
\text { whenever situation demands. Users can define who } \\
\text { call should be from. }\end{array}$ & $\begin{array}{l}\text { Unlike other apps, contacts entered by users as } \\
\text { 'guardians' in personal safety network are sent } \\
\text { an invitation to let them know guardian's role } \\
\text { in app \& they can accept or decline to serve as } \\
\text { user's guardian. }\end{array}$ & $\begin{array}{l}\text { Users cannot directly initiate contact with } \\
\text { police or other social services. } \\
\text { A premium service is available for a fee ( } \$ 20 \\
\text { annually or } \$ 30 \text { for two years), \& goes } \\
\text { beyond alerting your contacts/guardians by } \\
\text { providing } 24 \times 7 \text { monitoring by professional } \\
\text { security service centers. (Please Note: } \\
\text { Premium service is currently available only } \\
\text { in Norway, Sweden, \& South Africa. Will be } \\
\text { launched in US). } \\
\text { No access to supportive services, such as } \\
\text { counseling centers, social service agencies }\end{array}$ & $\begin{array}{l}\text { Street-based violence } \\
\text { prevention app } \\
\text { Individuals at risk of } \\
\text { experiencing violence } \\
\text { https://getbsafe.com/ (b- } \\
\text { Safe, 2016) }\end{array}$ \\
\hline $\begin{array}{l}\text { Lifeline } \\
\text { Response, } \\
\text { USA }\end{array}$ & $\begin{array}{l}\text { Fee-based personal safety app allows users to } \\
\text { trigger an alarm in event of an emergency or } \\
\text { untoward situation. If user within a stipulated time } \\
\text { does not disarm alarm, app automatically notifies } \\
\text { authorities \& their emergency contacts with links to } \\
\text { their last GPS location. }\end{array}$ & $\begin{array}{l}\text { During an emergency, if user cannot be } \\
\text { reached to verify their safety after setting } \\
\text { alarm, } 24 \times 7 \text { Lifeline Response call center } \\
\text { operators informs emergency dispatchers } \\
\text { (police, medical, fire department) with all } \\
\text { location details of user \& ensures that } \\
\text { emergency services reach user. } \\
\text { Allows users to deactivate alarm in case it was } \\
\text { triggered accidentally. } \\
\text { Has secret alarm feature which makes it seems } \\
\text { that app has been disabled, but in reality, it } \\
\text { automatically dials } 911 \& \text { prompts user to call } \\
\text { emergency contacts/lifelines that they had } \\
\text { specified in app. Also, a way to tell emergency } \\
\text { aids \& lifeline response verification center that } \\
\text { user is in trouble \& that they shouldn't call } \\
\text { user to verify. }\end{array}$ & $\begin{array}{l}\text { Smartphone only app; cannot operate on a } \\
\text { basic phone. } \\
\text { Indirect costs of purchasing data plans } \\
\text { Requires a subscription fee of } \$ 3.75 \text { per } \\
\text { month } \\
\text { No access to supportive services, such as } \\
\text { counseling centers, social service agencies }\end{array}$ & $\begin{array}{l}\text { Street-based violence } \\
\text { prevention \& } \\
\text { intervention app } \\
\text { Individuals at risk of } \\
\text { experiencing violence or } \\
\text { survivors of violence } \\
\text { http://llresponse.com/ }\end{array}$ \\
\hline
\end{tabular}




\section{Table 1. Features of Emergency Assistance Apps}

Name of the

App, Location Features of the app

Guardly, One-touch access to personal safety networks sends

USA

SOS alert notification to friends, family, \& campus

safety across US via phone call, SMS, \& email

Another tap on app enables user to escalate their

alert to include contacting authorities.

Allows users to configure groups of personal contacts for different emergency scenarios. Users can have one group of contact for health

emergencies \& another contact group for dating violence-related emergencies.

Guard My $\quad$ Free mobile app that allows users to designate a

Angel, USA few contacts to watch over in emergency situation

Users can set a timer for "angel" to watch over

them. For instance, if users are going alone for a

night walk, they can choose to designate a few

contacts to watch over them for set number of

hours. If user does not confirm during specified

period that they are safe, \& timer expires, app will

instantly notify user's pre-designated contacts via

SMS, email, \& Facebook posts with a google map link for their user's last location details.

React Mobile, Personal safety smartphone app used to prevent

USA

violence as well as to intervene in a situation. For instance, "Help me" tab of app allows you to alert your preregistered emergency contacts (friends or family) \& authorities via email \& SMS about your whereabouts in times of danger. Users contacts \& 911 officials receive a text \& email with user's GPS location. Option of making Facebook \&

Twitter post is also possible.

"Follow Me" tab allows users to let their contacts keep a virtual watch on their activity for a period in which they feel unsafe.

\section{Uniqueness of the app}

Fee-based service that goes beyond

otifications \& instantly connects users to

their contacts through a conference call, SMS,

instant messaging \& real-time location

tracking throughout an incident.

Additional built-in security features, including ability to snap/share photos \& sound loud whistle to deter potential assailants or draw attention to their situation.

Notification goes out when phone is disabled afterward.

Runs in background, does not interfere with phone's functions \& operates independently of battery life.

Provides option of buying wearable React

Sidekick device which looks like a keychain

Alerts friends \& authorities when phone is out of reach in times of emergency.

Has option to call $911 \&$ also to deactivate alert within 6 seconds.

No Subscription fee.
Limitations/Obstacles for social work

\section{clients}

Premium features of app like conference call,

ink to emergency response website, real-

time tracking \& audio-visuals of location may costs $\$ 9.99 /$ month or $\$ 99$ yearly.

Smartphone only app; cannot operate on a basic phone.

Indirect costs of purchasing data plans

No access to supportive services, such as counseling centers, social service agencies

Smartphone only app; cannot operate on a basic phone.

Indirect costs of purchasing data plans

Does not give users option to contact 911

dispatchers or summon other emergency services.

No access to supportive services, such as counseling centers, social service agencies

Smartphone only app; cannot operate on a basic phone.

Indirect costs of purchasing data plans or internet.

No access to supportive services, such as counseling centers, social service agencies
Type of Violence; Target Audience; Link to App

Street-based violence

prevention app

College-going women in

http://appsagainstabuse.d evpost.com/submissions/ 4899-guardly

Street-based violence prevention app

Individuals at risk of experiencing violence

https://www.myangelgua rd.com/

Street-based violence \& intervention prevention app

Individuals at risk of experiencing violence \& survivors of violence

https://reactmobile. 


\begin{tabular}{|c|c|c|c|c|}
\hline $\begin{array}{l}\text { Name of the } \\
\text { App, Location }\end{array}$ & Features of the app & Uniqueness of the app & $\begin{array}{l}\text { Limitations/Obstacles for social work } \\
\text { clients }\end{array}$ & $\begin{array}{l}\text { Type of Violence; Target } \\
\text { Audience; Link to App }\end{array}$ \\
\hline $\begin{array}{l}\text { StaySafe, } \\
\text { Internationally }\end{array}$ & $\begin{array}{l}\text { Smartphone-based personal safety app allows } \\
\text { user's family \& friends to know about their } \\
\text { whereabouts in case they get in trouble. App lets } \\
\text { users set an alert timer on their phone for any single } \\
\text { activity/ situations. Alarm timer can be deactivated } \\
\text { by user alone as it is password protected. If not } \\
\text { disabled by user, app will inform via email \& text } \\
\text { their emergency contacts with exact location details } \\
\text { of users. }\end{array}$ & $\begin{array}{l}\text { App has option to discreetly raise a panic alert } \\
\text { alarm using power button. } \\
\text { 4-digit pin code for ending tracked sessions. } \\
\text { Reminds users that their session is due to } \\
\text { expire in } 5 \text { minutes with an onscreen message. } \\
\text { Alerts from StaySafe are sent to emergency } \\
\text { contacts when phone is switched off, or } \\
\text { battery runs out of power. }\end{array}$ & $\begin{array}{l}\text { Smartphone only app; cannot operate on a } \\
\text { basic phone. } \\
\text { One-time fee of } \$ 6.99 \text { to purchase app. } \\
\text { Potential additional cost of purchasing data } \\
\text { plans or internet. } \\
\text { Users report that only one emergency contact } \\
\text { can be alerted. } \\
\text { Does not give users option to establish } \\
\text { contact with law enforcement authorities or } \\
911 \text { directly. } \\
\text { No access to supportive services, such as } \\
\text { counseling centers, social service agencies }\end{array}$ & $\begin{array}{l}\text { Street-based violence } \\
\text { prevention app } \\
\text { Individuals at risk of } \\
\text { experiencing violence } \\
\text { https://personalapp.stays } \\
\text { afeapp.com/ }\end{array}$ \\
\hline $\begin{array}{l}\text { Aspire News, } \\
\text { USA }\end{array}$ & $\begin{array}{l}\text { Personal safety mobile app designed for victims of } \\
\text { DV. Users can covertly send texts to their trusted } \\
\text { contacts in times of crisis. Help Section is } \\
\text { disguised as a newspaper app, but contains } \\
\text { complete resources for victims of DV, phone \#s of } \\
\text { women's shelters, \& helplines. } \\
\text { Tapping app three times will alert users' emergency } \\
\text { contacts to come to their immediate help. }\end{array}$ & $\begin{array}{l}\text { Disguised app that includes links for victims } \\
\text { of abuse to learn more about their situation \& } \\
\text { seek help. }\end{array}$ & $\begin{array}{l}\text { Smartphone only app; cannot operate on a } \\
\text { basic phone. } \\
\text { Indirect costs of purchasing data plans or } \\
\text { internet. } \\
\text { Does not give users option to efficiently \& } \\
\text { surreptitiously contact } 911 \& \text { provides a list } \\
\text { of domestic service providers, local shelter } \\
\text { options, reads about domestic abuse without } \\
\text { creating a browsing history. }\end{array}$ & $\begin{array}{l}\text { Intimate-partner violence } \\
\text { prevention \& } \\
\text { intervention app } \\
\text { Victims of DV } \\
\text { https://play.google.com/s } \\
\text { tore/apps/details?id=com } \\
\text { aspireapp\&hl=en_US }\end{array}$ \\
\hline
\end{tabular}




\begin{tabular}{|c|c|c|c|c|c|}
\hline $\begin{array}{c}\text { Name of the } \\
\text { App }\end{array}$ & Features of the app & Uniqueness of the app & Limitations/Obstacles & $\begin{array}{l}\text { Type of Violence; } \\
\text { Target Audience } \\
\text { Link to the App }\end{array}$ & $\begin{array}{l}\text { How can social } \\
\text { workers be included } \\
\text { in this app? }\end{array}$ \\
\hline $\begin{array}{l}\text { Bright Sky, } \\
\text { UK }\end{array}$ & $\begin{array}{l}\text { Free to download. Provides information } \\
\& \text { support services on issues of stalking } \\
\& \text { harassment, sexual violence } \& \\
\text { consent, \& domestic abuse. }\end{array}$ & $\begin{array}{l}\text { Secure My Journal tool to record incidents of } \\
\text { abuse via text, audio, video or photographs, } \\
\text { without any content being saved on device } \\
\text { itself. } \\
\text { Questionnaires for users to assess safety of } \\
\text { their relationship, with a section on } \\
\text { dispelling myths around domestic \& sexual } \\
\text { abuse. } \\
\text { Has unique UK-wide directory of specialist } \\
\text { domestic abuse support services with contact } \\
\text { details. } \\
\text { Available in } 4 \text { languages: English, Urdu, } \\
\text { Punjabi, \& Polish. }\end{array}$ & $\begin{array}{l}\text { Smartphone only app; } \\
\text { cannot operate on a basic } \\
\text { phone. } \\
\text { Indirect costs of } \\
\text { purchasing data plans or } \\
\text { internet. }\end{array}$ & $\begin{array}{l}\text { DV } \\
\text { Victims of domestic } \\
\text { abuse } \\
\text { https://www.hestia.o } \\
\underline{\text { rg/brightsky }}\end{array}$ & $\begin{array}{l}\text { Educate clients about } \\
\text { apps, particularly } \\
\text { clients who appear } \\
\text { reluctant to share their } \\
\text { information about } \\
\text { abuse with helping } \\
\text { professionals. }\end{array}$ \\
\hline MyPlan, USA & $\begin{array}{l}\text { Interactive safety decision aid for } \\
\text { college going women (18-24) } \\
\text { experiencing intimate partner violence } \\
\text { (IPV) as well as supporting their friends } \\
\text { \& family members in taking action } \\
\text { while keeping themselves safe. } \\
\text { Users can access tool via mobile app, } \\
\text { tablet or internet browser. } \\
\text { Components of app: } \\
\text { - Introduction on safety in relationship } \\
\text { - Danger assessment tool to assess for } \\
\text { safety } \\
\text { - My priorities decision-making tool } \\
\text { - My Plan provides a personalized } \\
\text { safety plan suggestion. }\end{array}$ & $\begin{array}{l}\text { Inconspicuous name } \& \text { logo \& password } \\
\text { protected. } \\
\text { Incorporates best practices for IPV, including } \\
\text { evidence-based assessment, individualized } \\
\text { feedback \& support. } \\
\text { Specifically tailored to meet needs of } \\
\text { survivors of IPV \& provides users with } \\
\text { danger risk assessment \& a checklist of } \\
\text { safety behaviors such as a safe place to go \& } \\
\text { someone from whom they can ask an } \\
\text { emergency loan of US } \$ 100 .\end{array}$ & $\begin{array}{l}\text { Smartphone only app; } \\
\text { cannot operate on a basic } \\
\text { phone. } \\
\text { Indirect costs of } \\
\text { purchasing data plans } \\
\text { Available only in English } \\
\text { \& Spanish language }\end{array}$ & $\begin{array}{l}\text { IPV } \\
\text { Friends of survivors } \\
\text { of violence \& } \\
\text { college-going } \\
\text { women at risk of } \\
\text { experiencing } \\
\text { violence in their } \\
\text { relationships. } \\
\text { https://www.myplan } \\
\text { app.org/home }\end{array}$ & $\begin{array}{l}\text { Educate \& train } \\
\text { survivors of violence as } \\
\text { well as their friends in } \\
\text { using this app \& } \\
\text { learning about their } \\
\text { safety in the dating } \\
\text { relationships. }\end{array}$ \\
\hline $\begin{array}{l}\text { Evidentiary } \\
\text { Abuse } \\
\text { Affidavit } \\
\text { (iEAA) App, } \\
\text { USA }\end{array}$ & $\begin{array}{l}\text { Provides victims with a step-by-step } \\
\text { method for legally creating \& recording } \\
\text { evidence of abuse histories that are } \\
\text { needed in order to prosecute the } \\
\text { perpetrator should the victim be harmed. }\end{array}$ & $\begin{array}{l}\text { Users of the app are given instructions on } \\
\text { how to prepare specialized documents that } \\
\text { will, when combined with other evidence } \\
\text { (e.g., police reports, phone records, medical } \\
\text { records, texts, voicemails), provide law } \\
\text { enforcement \& prosecutors with vital } \\
\text { information needed for an investigation \& } \\
\text { criminal case. }\end{array}$ & $\begin{array}{l}\text { Apple only app. Not } \\
\text { available to Android } \\
\text { smartphone users. } \\
\text { Costs } \$ 9.99 \text { for } \\
\text { downloading the app from } \\
\text { Apple iOS App store. }\end{array}$ & $\begin{array}{l}\text { IPV } \\
\text { Victims } \\
\text { experiencing } \\
\text { violence } \\
\text { https://docume } \\
\text { nttheabuse.com } \\
\text { Levidentiary- }\end{array}$ & $\begin{array}{l}\text { Educate victims about } \\
\text { this secure evidence } \\
\text { building resource. }\end{array}$ \\
\hline
\end{tabular}




\begin{tabular}{|c|c|c|c|c|c|}
\hline $\begin{array}{c}\text { Name of the } \\
\text { App }\end{array}$ & Features of the app & Uniqueness of the app & Limitations/Obstacles & $\begin{array}{l}\text { Type of Violence; } \\
\text { Target Audience } \\
\text { Link to the App }\end{array}$ & $\begin{array}{l}\text { How can social } \\
\text { workers be included } \\
\text { in this app? }\end{array}$ \\
\hline & & $\begin{array}{l}\text { Users can fill out the EAA documentation } \\
\text { pages \& they will be notarized utilizing an e- } \\
\text { notarization process. } \\
\text { Evidence is stored in a safe place with only } \\
\text { trusted contacts aware of its location. } \\
\text { To ensure the users safety from their abusers, } \\
\text { Apple app uses cloud technology to store } \\
\text { EAA in a forensically secured database \& not } \\
\text { on the victim's phone or computer. }\end{array}$ & & $\begin{array}{l}\frac{\text { abuse- }}{\text { affidavit/eaa }} \\
\underline{\underline{y}}\end{array}$ & \\
\hline $\begin{array}{l}\text { Love is Not } \\
\text { Abuse }\end{array}$ & $\begin{array}{l}\text { App to teach parents about teen dating } \\
\text { violence/abuse \& also providing them } \\
\text { with information on what actionable } \\
\text { steps they can take to prevent abuse of } \\
\text { their children. }\end{array}$ & $\begin{array}{l}\text { Users can watch educational videos on how } \\
\text { to tackle dating violence experienced by their } \\
\text { children. }\end{array}$ & $\begin{array}{l}\text { Available only to users of } \\
\text { Apple devices; not } \\
\text { available to Android } \\
\text { smartphone users. }\end{array}$ & $\begin{array}{l}\text { Dating violence } \\
\text { Parents of children } \\
\text { experiencing dating } \\
\text { violence } \\
\text { https://www.techsaf } \\
\underline{\text { ety.org/loveisnotabu }} \\
\underline{\text { se/ }}\end{array}$ & $\begin{array}{l}\text { Direct parents to these } \\
\text { resources for learning } \\
\text { about dating violence. }\end{array}$ \\
\hline
\end{tabular}


Crowdsourcing reporting apps. The crowdsourcing reporting apps presented in Table 1 are useful in providing a more nuanced understanding of the reasons, patterns, and mechanisms through which violence spreads in any given region. Crowdsourcing apps are a beneficial tool in a society where violence against women is dismissed, negated or yet to be recognized as a systemic issue, as witnessed in the case of Egypt using HarassMap App (Peuchaud, 2014). In contexts where culture of silence prevails, the \#Metoo \& \# TimesUp movement serves as a useful example of how crowdsourcing reporting platforms can not only raise public awareness about an interrelated systemic issue of workplace sexual harassment and gender inequality but also some creative solutions to these complex problems (Choo, Byington, Johnson, \& Jagsi, 2019). For instance, a study aimed at interviewing people who contributed stories of harassment online using Hollaback! reported that online storytelling had a transformative effect on the cognitive and emotional experience and their understanding of the problem (Dimond, Dye, LaRose, \& Bruckman, 2013). This study noted that a shift occurred in the minds of women about the knowledge of street harassment as a larger problem tied to their right to public space and freedom. The study also revealed that online sharing of stories resulted in participants proactively responding and learning how to tackle the issue of street sexual harassment in the future.

Many of the reasons for non-reporting of violence, such as privacy concerns, fear of reprisal, sympathy for the offender, police leniency (Felson, Messner, Hoskin, \& Deane, 2002), embarrassment/shame, and the incident being too trivial to report (Birdsey \& Snowball, 2013) are well addressed when the users are given the option to make an anonymous report of the incident. For instance, HarrassMap allows users to report and share their sexual harassment experience anonymously and also give users access to resources and support from the online community (Young, 2014). As per the report evaluating the HarassMap initiative aimed at ending the social acceptability of violence in Egypt, the online reporting mechanisms had 88,851 visits per year and received an average of 40 reports per month, with 700 accurate reports in a year (HarassMap, 2012). Therefore, anonymity in reporting is a critical feature that needs to be built into the violence prevention apps for individuals to come forward and share their stories of violence.

Table 1 indicates that the crowdsourcing reporting apps are designed with the capabilities of not only making incident reports but also linking affected individuals with appropriate services, such as police, legal counseling, online support groups, and available local resources. If users do not perceive any direct benefit, then they will not make reports of violence. For instance, a study examining the barriers to reporting of domestic violence incidents to police found that victims were less likely to report if the police are not sufficiently understanding or proactive in their handling of domestic violence cases (Birdsey \& Snowball, 2013). Another study conducted by Cornell University and Hollaback! found that taking action "generally has a positive influence on targets emotional response to the experience of street harassment" (Livingston et al., 2012, p. 3) as it can help victims avoid the stigma and proactively seek help. Collectively, these findings suggest that users are more likely to report violence if they directly benefit from making such reports, such as gaining direct access to existing resources and information on violence prevention in their location. 
Another aspect crucial to improving the usability of these apps is the required reporting format of the incident. If the form for reporting is too complicated, or if there are too many required questions posed to the victims, or if the format is too rigid, that is only written reports are accepted, it may cater to the needs of only literate groups. For instance, if users can report the incident using video, audio or images, then it is possible for users who are not so literate to make a report and avail the services. Also, mandating a particular type of information can act as a deterrent depending on the situation. For instance, for project Women Under Siege, it is mandatory to describe the incident, a title for the event, type of harm, and their location to make a report (Women Under Siege, 2015). However, Hollaback! does not mandate any form of information but instead allows users to provide only information that they choose to share (Hollaback!, 2016).

The geographical coverage of these apps to users is also determined by the language supported in these apps. For instance, the Open Institute's gender-based violence project used "Ushahidi map-based tool" in the Khmer language to reach out to a broader audience in Indonesia. Similarly, projects like Women Under Siege, Hollaback, and Harrasmap support local languages have greater reach. A report titled The Impact of App Translations, prepared by Distomo Analytics (2012) showed that localizing iPhone apps by including native languages in the text feature led to a $128 \%$ rise in downloads. Availability of different languages is particularly important when working with culturally diverse populations in the United States.

Further, most app developers realize that cost is a significant barrier to the usage of apps; as a result, most apps are free to download. However, the use of apps often results in the use of data, which is a crucial concern because data plan expenses may discourage use. As a result, the privilege of being able to use these apps may remain in the domain of an "elite" section of society. Marginalized groups, such as poor, vulnerable women, who are at an increased risk of facing violence, are less likely to be able to afford the extra cost. The availability of unlimited data plans for a subsidized rate by the government for socially and economically marginalized groups may alleviate this problem in the future.

Emergency assistance apps. Table 2 indicates that the emergency assistance apps can serve as an intervention tool. For instance, some of the apps like Guard My Angel, ReactMobile, BSafe and StaySafe's "Follow Me" or "Watch over Me" feature allows users to let their emergency contacts know their whereabouts when venturing out alone. These apps act as a strong deterrent once the perpetrator gets to know that the app has contacted 911 or some other emergency contacts. While these emergency assistance apps may be effective against street violence, they may not work against domestic violence.

Apps like Aspire News are designed to meet the needs of women in abusive intimatepartner relationships. Some of the obstacles that users, particularly the social worker's client might face in making use of these apps are as follows: First, the registration requirements can deter some users from using the app as most of the apps require users to register with an email or Facebook account. Second, access to the apps becomes a real issue if users have to incur additional cost, as some of the apps like LifeLine Response, BSafe, and StaySafe have a monthly subscription fee, a one-time fee, or charge users for their premium features like "Follow Me" or sending alerts to first-line responders. All of 
the apps listed in Table 2 are designed for users who can afford smartphones and data plans which cost more than traditional phones. In addition, if the perpetrator also has complete control over the victim's finances, then a line item on a credit card bill for something like "StaySafe" could put a victim in more danger if their perpetrator notices it.

The third factor limiting the usability of cell phone apps is the issue of literacy as most of these apps are written solely in English. Non-English speaking individuals may not be able to use the apps.

Fourth, since apps are typically not designed to work across the multiple smartphone platforms, such as Android, iPhone, Blackberry, or Windows, it can be challenging for users to come up with their list of trusted emergency contacts that are on the same platform. The trusted contacts might not have smartphones that support their software platforms.

Fifth, it is essential to assess the safety of the users when reviewing various SMS alertbased emergency assistance apps. Like Panic Button and Aspire News, apps should be disguised. Users should have the option to choose between whether they want the alert to be concealed or not depending on the situation. Also, users should have the choice of establishing direct contact with law enforcement like Pukar, Guardly, Guard My Angel, LifeLine Response, and React Mobile.

Finally, to help increase the safety of individuals, there needs to be access to supportive services which only EyeWatch, Circle of Six, Panic Button and Aspire News App features. In general, the names of the app should also be covert and culturally appropriate names, like Pukar in India which means "Shout out" and is a very generic name.

Self-help assessment/learning apps. Table 3 shows how interactive smartphone apps can be designed to increase awareness about domestic abuse and the resources and support available in the local community to address domestic abuse, cyberstalking, and dating violence. This is quite a constructive use of cell phone technology as much of the education that happens in face-to-face interactions with social workers can be done through the medium of cell phones - minus the associated feeling of being judged. Apps like MyPlan, Love is Not Abuse, and Bright Sky are designed to educate users about the dangers of unhealthy relationships and the warning signs of abusive relationships and how to help victims of abuse. Social workers can direct their clients to these resources in case they find their clients are reluctant to broach the topic due to fears of being judged or further victimized. The Evidentiary Abuse Affidavit (iEAA) App goes a step further by helping build a strong legal case against the abuser (Document the Abuse, 2016). This app enables users to create safe, reliable and effective evidentiary documentation about abuse, which can be used for the prosecution of perpetrators. This is a very unique feature of this app as it eases the process of collecting evidence for survivors, but may be prohibitively expensive. While the MyPlan app is a research-based app developed with input from survivors of abuse and includes the Danger Assessment Survey (Alhusen et al., 2015), this app is currently available only in Spanish and English. On the contrary, Bright Sky app is available to users in English, Urdu, Punjabi, and Polish. For broader reach, these apps need to be made available in local languages. 


\section{Implications for Social Work Practice}

Based on the description of the varied mobile phone-based violence prevention apps, we recommend that social workers take the lead in evaluating the impacts of the technology on their clients, mainly how use or non-use of these mobile phone apps are affecting their clients. The NASW Code of Ethics states that

...social workers should assess the client's suitability and capacity for electronic and remote services. Social workers should consider the clients' intellectual, emotional, and physical ability to use technology to receive services and the clients' ability to understand the potential benefits, risks, and limitations of such services. If clients do not wish to use services provided through technology, social workers should help them identify alternate methods of service (NASW, 2017a, Standard 1.03 g, p. 8)

While it is clear from the review of these apps that affordability of smartphone apps might be an issue for economically and socially marginalized clients, the NASW Code of Ethics also states that "social workers should act to expand choice and opportunity for all people, with special regard for vulnerable, disadvantaged, oppressed, and exploited people and groups" (NASW, 2017a, Standard 6.04 b, p. 30), who are highly prone to experiencing violence and should enjoy the right to affordable internet access and digital literacy. Social workers should advocate for the use of the crowdsourcing reporting apps at the agency level to develop evidence-based violence prevention campaigns and programs. Rather than staying focused on survivors of violence, social workers can raise community awareness among bystanders about these apps so that they can intervene and act in ways that would show direct support to the survivors of violence. Also, social workers, through their governing bodies such as NASW, CSWE, and CSWA advocate for funding to provide coupon codes that allow people to get the apps at a discounted price so it's more accessible to more people.

Scholars have argued that whatever social workers do in their face-to-face interaction with clients, can now be done online using e-therapy (Santhiveeran, 2009), online counseling/therapy (Rochlen, Zack, \& Speyer, 2004; Ross, 2011; Shaw \& Shaw, 2006), and telehealth (Peddle, 2007). The literature also acknowledges several benefits of technology-based interventions in practice, such as enhanced inter-professional communication and clinical decision-making, streamlined case management and improved client access to data, rapid assessment, and clinical interventions, and enhanced client selfmanagement and self-efficacy (Craig \& Lorenzo, 2014). The benefits of technology-based interventions can be reaped only if social workers are trained and educated on the ethical, technical, and cultural issues that come in the way of implementation of these apps. For instance, social work practitioners working in the field of violence against women can use technology to innovatively meet the challenging and complex demands of their job. When working with clients residing in rural areas or who would otherwise not seek formal services, social workers can guide them to the self-help assessment/learning apps like MyPlan, Love is Not Abuse, Bright Sky, and Evidentiary Abuse Affidavit (iEAA) App. Hawkins, Pearce, Skeith, Dimitruk, and Roche (2009) found that when social workers used hand-held technological devices as opposed to paper-and-pencil questionnaires to screen 
for domestic abuse and neglect while out in the community, there was a significant reduction in collection of redundant domestic abuse data and more effective mobilization of resources, initiation of same-day in-depth social work assessment, and referrals to appropriate community agencies. Further, in the case of victims of rape and sexual assault, the availability of crowdsourcing reporting apps can make it easier for clients to take the first step of anonymously reporting the incident and seeking online support and services without the fear of being judged.

Social work practitioners should be made aware that a one-size-fits-all approach will not work and to keep in mind the unique needs of their clientele when considering programs, policies, and practices involving the use of technology (NASW, 2017b). For instance, Circle of 6 is a personal safety app designed for college students and is based on the assumption that individuals using this app will have six friends to add in the circle. This app might not apply to clients who are stigmatized and living a life of isolation and fear, such as women in the sex trade or survivors of trafficking who might not have six friends. As a result, social workers need to educate themselves first about the purpose of the app and make clients aware of the possible benefits and limitations of each app in their therapy. Social workers providing counseling to clients at risk of high violence can ask them to make use of the emergency assistance apps listed in Table 2 and opt to be listed as their emergency contacts or call guardians so that they can take immediate steps to remedy the situation. This is particularly useful for clients who have had previous brushes with law enforcement or criminal histories and may fear contacting the police authorities. Social work agencies can also create a circle of support for their vulnerable and isolated clients by asking them to watch out for each other through these emergency assistance apps.

\section{Implications for Future Research}

Unlike MyPlan - an interactive safety decision app for college women in abusive dating relationships and their friends (Alhusen et al., 2015) and iEAA app, there are very few apps that are grounded in research that is based on the input of survivors of different types of violence and targeted population. Therefore, future research should evaluate the effectiveness of these mobile phone-based applications for violence prevention in different settings and target populations. Social workers should actively study the consumer perspective on app-based violence prevention interventions, particularly how mobile apps have changed the lives of their clients and how they prefer the services to be delivered. We recommend that the design and development of mobile phone-based interventions be based on the input and feedback from social workers with expertise in the field of violence prevention as they will be better able to speak to the risks, safety issues, and socioeconomic challenges of their clients with regards to using ICTs.

\section{Conclusion}

This article surveyed mobile phone-based interventions for violence prevention and has offered critical insights on the purpose, benefits, and challenges associated with the use of mobile phone apps-based interventions for violence prevention. The different types of apps for violence prevention and intervention include crowdsourcing reporting apps, SMS alert-based emergency assistance apps, and self-help learning/assessment apps. Each app 
is designed to address the issue of violence at different levels. Crowdsourcing apps aim to increase community awareness as well as community ownership for dealing with the problem of violence, whereas SMS alert-based emergency assistance apps and selfeducation apps tackle the issue of abuse at the individual level. Social workers working in the field of violence prevention need to be aware that through these apps they can monitor their client's status in real time and respond rapidly to clients with resources and support in crises. Many times, a delay in response time, paperwork, long travel times, and the fear of being judged act as barriers for clients in accessing formal institutional services, such as counseling centers, and criminal justice interventions such as protective orders or arrest warrants. The review of these mobile phone apps indicates that the use of technology can enable clients to access violence prevention resources without the fear of being judged and can be instrumental in creating a secure support network for victims. As a result, social workers responsible for conducting the biopsychosocial assessments with clients should also evaluate the technology needs of their clients and their comfort with using technology, particularly their digital literacy skills and challenges (NASW, 2017b).

Additionally, social workers can play a crucial role in collaborating with ICT professionals in the design and development of socially and culturally relevant mobilephone-based interventions that take into consideration the unique needs of their diverse clients, such as the issue of affordability, language, and the preference for different medium of electronic communication (interactive voicemail, text, email, phone, video). Since social workers typically work with economically and socially marginalized groups and are responsible for advocating for social change and social justice issues experienced by these groups, they are well-positioned to leverage their client's position, enhance the clientworker relationship, and fulfill the promise of equal and ethical digital citizenship (Henry \& Powell, 2016). Social workers can play a significant role in advocating for low -cost internet and subsidized smartphone devices for the economically marginalized population as they have a right to digital literacy and internet access. In addition, social workers can also rally for funding to work with app developers to provide a low-cost or free download of the app for those who may not be able to afford the app costs.

\section{References}

Aguirre, T. P. R., McCoy, K. M., \& Roan, M. (2013). Development guidelines from a study of suicide prevention mobile applications (Apps). Journal of Technology in Human Services, 31, 269-293. doi: https://doi.org/10.1080/15228835.2013.814750

Alhusen, J., Bloom. T., Clough, A., \& Glass N. (2015). Development of the MyPlan safety decision app with friends of college women in abusive dating relationships, Journal of Technology in Human Services, 33(3), 263-282. doi: https://doi.org/10.1080/15228835.2015.1037414

Amnesty International. (2016). Panic button App. Retrieved from https://panicbutton.io/

bSafe. (2016). bSafe: Never walk alone. Retrieved from https://getbsafe.com/

Birdsey, E., \& Snowball, L. (2013). Reporting violence to police: A survey of victims attending domestic violence services (Crime and Justice Statistics Bureau Brief Issue Paper No. 91). Sydney: NSW Bureau of Crime Statistics and Research. Retrieved 
from

https://www.women.nsw.gov.au/_data/assets/pdf_file/0004/280912/Reporting_Viol ence to the Police - BOCSAR survey.pdf

Brathwaite, R. (2012, December). 16 Tech Innovations that Help the Movement to Prevent and Stop Violence Against Women. The Pixel Project's "16 for 16" Campaign. Retrieved from http://16days.thepixelproject.net/16-tech-innovationsthat-help-the-movement-to-prevent-and-stop-violence-against-women/

Choo, E. K., Byington, C. L., Johnson, N.-L., \& Jagsi, R. (2019). From \#MeToo to \#TimesUp in health care: can a culture of accountability end inequity and harassment? Lancet (London, England), 393(10171), 499-502. doi: https://doi.org/10.1016/S0140-6736(19)30251-X

Circle of 6. (2016). Retrieved from http://www.circleof6app.com/

Collins, P. (1999). Black feminist thought. New York. Routledge

Craig, S. L., \& Lorenzo, M. V. C. (2014). Can information and communication technologies support patient engagement? A review of opportunities and challenges in health social work. Social work in health care, 53(9), 845-864. doi: https://doi.org/10.1080/00981389.2014.936991

Cumiskey, M. K., \& Brewster, K. (2012). Mobile phones or pepper spray? Imagined mobile intimacy as a weapon of self-defense for women. Feminist Media Studies, 12(4), 590-599. doi: https://doi.org/10.1080/14680777.2012.741893

Dean, A. L., Makin, J. D., Kydd, A. S., Biriotti, M., \& Forsyth, B. W. (2012). A pilot study using interactive SMS support groups to prevent mother-to-child HIV transmission in South Africa. Journal of Telemedicine and Telecare, 18(7), 399-403. doi: https://doi.org/10.1258/jtt.2012.120118

Dimond, P. J., Dye, M., LaRose, D., \& Bruckman, S. A. (2013). Hollaback! The role of collective storytelling online in a social movement organization. Paper presented at the Making the World a Better place, 2013 Conference on Computer Supported Cooperative Work (CSCW), San Antonio, TX. Retrieved from https://dl.acm.org/citation.cfm?id=2441831

Dimond, J. P., Fiesler, C., \& Bruckman, A. (2011). Domestic violence and information communication technologies. Interacting with Computers, 23, 413-421. doi: https://doi.org/10.1016/j.intcom.2011.04.006

Distimo Analytics. (2012). The impact of App translations (Monthly Webinar Report). Retrieved from https://www.slideshare.net/distimo/distimo-month-report-webinaroctober-2012

Document the Abuse. (2016). Evidentiary abuse affidavit app. Retrieved from http://documenttheabuse.com/

Eden, K., Perrin, N., Hanson, G., Messing, J., Bloom, T., Campbell, J., ... Glass, N. (2014). Use of online safety decision aid by abused women: Effect on decisional 
conflict in a randomized controlled trial. American Journal of Preventive Medicine, 48(4), 372-383. doi: https://doi.org/10.1016/j.amepre.2014.09.027

Felson, R. B., Messner, S. F., Hoskin, A. W., \& Deane, G. (2002). Reasons for reporting and not reporting domestic violence to the police. Criminology, 40(3), 617-647. doi: https://doi.org/10.1111/j.1745-9125.2002.tb00968.x

Glass, N., Clough, A., Case, J., Hanson, G., Waterbury, A., Barnes-Hoyt, J., .... Perrin, N. (2015). A safety app to respond to dating violence for college women and their friends: The MyPlan study randomized controlled trial protocol. BMC Public Health, 15, 871, pp. 1-13. doi: https://doi.org/10.1186/s12889-015-2191-6

Glass, N., Eden, B. K., Bloom, T., \& Perrin, N. (2010). Computerized Aid Improves Safety Decisions Process for Survivors of Intimate Partner Violence. Journal of Interpersonal Violence, 25(11), 1947-1964. doi: https://doi.org/10.1177/0886260509354508

Glass, N., Perrin, N., Hanson, G., Bloom, T., Messing, J., Clough, A., ....Eden, K. (2017). The longitudinal impact of an internet safety decision aid for abused women. American Journal of Preventive Medicine, 52(5), 606-615. doi: https://doi.org/10.1016/j.amepre.2016.12.014

Hague, C. (2010). "It's Not Chalk and Talk Anymore": School approaches to developing students' digital literacy. Retrieved April 3, 2019, from NFER website: https://www.nfer.ac.uk/its-not-chalk-and-talk-anymore-school-approaches-todeveloping-students-digital-literacy/

HarassMap. (2012). Brief: First Annual Report. December 2010-March 2012. Retreived from https://s3-eu-west-1.amazonaws.com/harassmap/media/uploadedfiles/HarassMap-Report-English-Brief-Final.pdf

HarassMap. (2015). Report Harassment. Retrieved from https://harassmap.org/en/

Hawkins, J. W., Pearce, C. W., Skeith, J., Dimitruk, B., \& Roche, R. (2009). Using technology to expedite screening and intervention for domestic abuse and neglect. Public Health Nursing, 26(1), 58-69. https://doi.org/10.1111/j.15251446.2008.00754.x

Heerde, J. A., \& Hemphill, S. A. (2019). Associations between individual-level characteristics and exposure to physically violent behavior among young people experiencing homelessness: A meta-analysis. Aggression and Violent Behavior, 47, 46-57. doi: https://doi.org/10.1016/j.avb.2019.03.002

Henry, N., \& Powell, A. (2015). Beyond the 'sext': Technology-facilitated sexual violence and harassment against adult women. Australian \& New Zealand Journal of Criminology, 48(1), 104-118. doi: https://doi.org/10.1177/0004865814524218

Henry, N., \& Powell, A. (2016). Sexual violence in the digital age: The scope and limits of criminal law. Social \& Legal Studies, 25(4), 397-418. doi: https://doi.org/10.1177/0964663915624273 
hooks, b. (2000). Feminism is for everybody: Passionate politics. Cambridge, MA: South End Press.

Hollaback! (2016). Take action. Retrieved from https://www.ihollaback.org/take-action/

Hostler, J. M., \& O’Neil, M. (2018, April 17). Reframing sexual violence: From \#MeToo to Time's Up. Stanford Social Innovation Review: Informing and Inspiring Leaders of Change. Retrieved from https://ssir.org/articles/entry/reframing_sexual_violence_from metoo to times up

Ingersoll, K., Dillingham, R., Reynolds, G., Hettema, J., Freeman, J., Hosseinbor, S., \& Winstead-Derlega, C. (2014). Development of a personalized bidirectional text messaging tool for HIV adherence assessment and intervention among substance abusers. Journal of Substance Abuse Treatment, 46(1), 66-73. doi: https://doi.org/10.1016/j.jsat.2013.08.002

Jones, J. (2014, June 1). 4 free apps to help college women feel safe. USA Today. Retrieved from https://www.usatoday.com/story/college/2014/06/01/4-free-apps-tohelp-college-women-feel-safer/37391545/

Kalra, G., \& Bhugra, D. (2013). Sexual violence against women: Understanding crosscultural intersections. Indian Journal of Psychiatry, 55(3), 244-249. doi: https://doi.org/10.4103/0019-5545.117139

Kwon, H., Cho, J., Kim, H., Lee, J. H., Song, B. R., Oh, J. A.,. ....Yoon, K. H. (2004). Development of web-based diabetic patient management system using short message service (SMS). Diabetes Research and Clinical Practice, 66, S133-S137. doi: https://doi.org/10.1016/j.diabres.2003.10.028

Levine, D., McCright, J., Dobkin, L., Woodruff, J. A., Klausner, D. J. (2008). SEXINFO: A sexual health text messaging service for San Francisco Youth. American Journal of Public Health, 98, (3), 393-395. doi: https://doi.org/10.2105/AJPH.2007.110767

Lindsay, M., Messing, J. M., Thaller, J., Baldwin, A., Clough, A., Bloom, T., Eden, B. K., \& Glass, N. (2013). Survivor feedback on a safety decision aid smartphone application for college-age women in abusive relationships, Journal of Technology in Human Services, 31(4), 368-388. doi: https://doi.org/10.1080/15228835.2013.861784

Livingston, B., Wagner, K. C., Diaz, S., \& Liu, A. (Eds.). (2012). The experience of being targets of street harassment in NYC: Preliminary findings from a qualitative study of a sample of 223 voices who Hollaback! Worker Institute at Cornell University and Hollaback! Retrieved from https://www.ihollaback.org/fact-sheet-theexperience-of-being-targets-of-street-harassment-in-nyc/

Lopez, A. (2014). Social work, technology, and ethical Practices: A review and evaluation of the National Association of Social Worker's Technology Standards, Social Work in Health Care, 53, 9, 815-833. doi: https://doi.org/10.1080/00981389.2014.943454 
Mancini, F., \& O'Reilly, M. (2013). New Technology and the Prevention of Violence and Conflict. Stability: International Journal of Security \& Development,2 (3), 1-9,55 doi: http://doi.org/10.5334/sta.cp

Mangone, R. E., Lebrun, V., \& Muessig, E. K. (2016). Mobile phone Apps for the prevention of unintended pregnancy: A systematic review and content analysis, JMIR mhealth and uhealth, 4(1), e6. doi: https://doi.org/10.2196/mhealth.4846

Martinez-Pecino, R., \&Durán, M. (2016). I love you but I cyberbully you: The role of hostile sexism. Journal of Interpersonal Violence. 34(4), 812-825. doi: https://doi.org/10.1177/0886260516645817

Mason, C., \& Magnet, S. (2012). Surveillance studies and violence against women. Surveillance \& Society, 10 (2), 105-118. doi: https://doi.org/10.24908/ss.v10i2.4094

Mbuagbaw, L., Thabane, L., Ongolo-Zogo, P., Lester, R. T., Mills, E. J., Smieja, M., \& Kouanfack, C. (2012). The Cameroon mobile phone SMS (CAMPS) trial: A randomized trial of text messaging versus usual care for adherence to antiretroviral therapy. PloS ONE, 7(12), e46909 [pp. 1-7]. doi: https://doi.org/10.1371/journal.pone.0046909

Murray, C., Nemati, H., White, J., Chow, A., \& Pow, A. (2015). Domestic violence service providers' needs and perceptions of technology: A qualitative study. Journal of Technology in Human Services, 33(2), 133-155. doi: https://doi.org/10.1080/15228835.2014.1000558

National Association of Social Workers [NASW]. (2017a). Code of Ethics of the National Association of Social Workers, Washington, DC. National Association of Social Workers.

NASW. (2017b). NASW, ASWB, CSWE \& CSWA Standards for Technology in Social Work Practice. Washington, DC: Author. Retrieved from https://www.socialworkers.org/LinkClick.aspx?fileticket=lcTcdsHUcng\%3D\&portali $\underline{\mathrm{d}=0}$

Obermayer, L., J.,William, T, R., Ofer, A., \& Jersino, J. M. (2004).College smokingcessation using cell phone text messaging, Journal of American College Health, 53(2), 71-78. doi: https://doi.org/10.3200/JACH.53.2.71-78

Overstreet, N. M., \& Quinn, D. M. (2013). The Intimate Partner Violence Stigmatization Model and Barriers to Help-Seeking. Basic and Applied Social Psychology, 35(1), 109-122. doi: https://doi.org/10.1080/01973533.2012.746599

Parrott L., \& Madoc-Jones I. (2008). Reclaiming information and communications technology for empowering social work practice. Journal of Social Work, 8(2), 181197. doi: https://doi.org/10.1177/1468017307084739

Peddle, K. (2007). Telehealth in context: Socio-technical barriers to telehealth use in Labrador, Canada. Computer Supported Cooperative Work (CSCW), 16(6), 595-614. doi: https://doi.org/10.1007/s10606-006-9030-3 
Perron, B. E., Taylor, H. O., Glass, J. E., \& Margerum-Leys, J. (2010). Information and communication technologies in social work. Advances in Social Work, 11(2), 67-81.

Peuchaud, S. (2014). Social media activism and Egyptians' use of social media to combat sexual violence: An HiAP case study, Health Promotion International, 29 (1), i113i120. doi: https://doi.org/10.1093/heapro/dau046

Puccio, A. J., Belzer, M., Olson, J., Martinez, M., Salata, C., Tucker, D., \& Tanaka, D. (2006). The use of cell phone reminder calls for assisting HIV-infected adolescents and young adults to adhere to highly active antiretroviral therapy: A Pilot Study. AIDS Patient Care and STDs, 20(6), 438-444. doi: https://doi.org/10.1089/apc.2006.20.438

Ramsey, A. T., \& Montgomery, K. (2014). Technology-based interventions in social work practice: A systematic review of mental health interventions. Social Work in Health Care, 53(9), 883-899. doi: https://doi.org/10.1080/00981389.2014.925531

Robbins, P. S., Coe Regan, J. A., Williams, H. J., Smyth, J. N., \& Bogo, M.(2016) From the Editor-The future of social work education, Journal of Social Work Education, 52(4), 387-397. doi: https://doi.org/10.1080/10437797.2016.1218222

Rochlen, A. B., Zack, J. S., \& Speyer, C. (2004). Online therapy: Review of relevant definitions, debates, and current empirical support. Journal of clinical psychology, 60(3), 269-283. doi: https://doi.org/10.1002/jclp.10263

Rodgers, A., Corbett, T., Bramley, D., Riddell, T., Wills, M., Lin, R. B., \& Jones, M. (2005). Do you smoke after txt? Results of a randomized trial of smoking cessation using mobile phone text messaging. Tobacco control, 14(4), 255-261. doi: https://doi.org/10.1136/tc.2005.011577

Rodrigues R., Shet A., Antony J., Sidney K., Arumugam K., Krishnamurthy, S.,... DeCosta, A. (2012). Supporting adherence to antiretroviral therapy with mobile phone reminders: Results from a cohort in south India. PLoS ONE, 7(8), e40723 [pp. 1-7]. doi: https://doi.org/10.1371/journal.pone.0040723

Rosenthal, L. (2013). Eliminate violence against women and girls? There's an app for that. Science Progress. Retrieved from https://scienceprogress.org/2013/03/eliminateviolence-against-women-and-girls-worldwide-there $\% \mathrm{E} 2 \% 80 \% 99 \mathrm{~s}$-an-app-for-that/

Ross, W. (2011). Ethical issues involved in online counseling. Journal of Psychological Issues in Organizational Culture, 2(1), 54-66. https://doi.org/10.1002/jpoc.20047

Santhiveeran, J. (2009). Compliance of social work e-therapy websites to the NASW code of ethics. Social Work in Health Care, 48(1), 1-13. doi: https://doi.org/10.1080/00981380802231216

Shaw, H. E., \& Shaw, S. F. (2006). Critical ethical issues in online counseling: Assessing current practices with an ethical intent checklist. Journal of Counseling \& Development, 84(1), 41-53. doi: https://doi.org/10.1002/j.1556-6678.2006.tb00378.x 
Shaw, S., \& Lee, J. (2014). Women's voices, feminist visions. New York, NY: McGraw Hill.

Vidrine, D. J., Arduino, R. C., Lazev, A. B., \& Gritz, E. R. (2006). A randomized trial of a proactive cellular telephone intervention for smokers living with HIV/AIDS. AIDS, 20(2), 253-260. doi: https://doi.org/10.1097/01.aids.0000198094.23691.58

Walls, N. E., Atteberry-Ash, B., Kattari, S. K., Peitzmeier, S., Kattari, L., \& Langenderfer-Magruder, L. (2019). Gender Identity, Sexual Orientation, Mental Health, and Bullying as Predictors of Partner Violence in a Representative Sample of Youth. Journal of Adolescent Health, 64(1), 86-92. doi: https://doi.org/10.1016/j.jadohealth.2018.08.011

Westmarland, N., Hardey, M., Bows, H., Branley, D., Chowdhury, M., Wheatley, K., \& Wistow, R. (2013). Protecting women's safety? The use of smartphone 'apps' in relation to domestic and sexual violence. Society for Applied Social Sciences, Durham University, Research Briefing, Issue No 12. Retrieved from https://www.dur.ac.uk/resources/sass/research/briefings/ResearchBriefing12ProtectingWomensSafety.pdf

Women Under Siege. (2015). Women's media center's: Documenting sexualized violence in Syria. Submit a New Report. Retrieved from https://womenundersiegesyria.crowdmap.com/reports/submit

Young, C. (2014). HarassMap: Using crowdsourced data to map sexual harassment in Egypt. Technology Innovation Management Review, 4, 7-13. doi: https://doi.org/10.22215/timreview/770

Zraick, K. (2010, November 7). New phone apps aim to combat harassment. Retrieved from The New York Times: https://www.nytimes.com/2010/11/08/nyregion/08hollaback.html

Author's note: Address correspondence to: Dr. Sunny Sinha, Associate Professor, School of Social Work, Marywood University, Immaculata Hall, Room 205, 2300, Adams Avenue, Scranton, Pennsylvania- 18509. E-mail: sinha.sunny@marywood.edu; Dr. Aviral Shrivastava, Associate Professor, School of Computing Informatics and Decision Systems Engineering, Arizona State University, Centerpoint 203-15, 660 South Mill Avenue, Tempe, Arizona-85281. Email: aviral.shrivastava@asu.edu

Funding: This research project was supported by the Marywood University's Research Initiation Grant.

Acknowledgement: We would like to thank the anonymous reviewers of this journal for their excellent feedback and very grateful to Marywood University for a grant that laid the groundwork for this research project. In addition, many thanks to Indulata Prasad and Ilya Issenin for their encouraging and helpful comments on the earlier draft of this paper. 